Western University

Scholarship@Western

Philosophy Publications

Philosophy Department

2007

For Dignity or Money: Feminists on the Commodification of Women's Reproductive Labour

Carolyn McLeod

The University of Western Ontario, cmcleod2@uwo.ca

Follow this and additional works at: https://ir.lib.uwo.ca/philosophypub

Part of the Bioethics and Medical Ethics Commons, Feminist, Gender, and Sexuality Studies Commons, and the Philosophy Commons

Citation of this paper:

McLeod, Carolyn, "For Dignity or Money: Feminists on the Commodification of Women's Reproductive Labour" (2007). Philosophy Publications. 338.

https://ir.lib.uwo.ca/philosophypub/338 


\title{
FOR DIGNITY OR MONEY: FEMINISTS ON THE COMMODIFICATION OF WOMEN'S REPRODUCTIVE LABOUR
}

\author{
CAROLYN MCLEOD
}

RACHEL is a beautiful woman who is faced with a difficult choice. She is in love with a handsome man; yet if she chooses to be with him, she may be happy but she won't be rich. She could choose to be without him, however, and take a million dollars instead, in which case she would be rich but alone. What to do? If you think women only face this sort of question on the hit American reality television

I am grateful to Amanda Porter for her research assistance and to Bonnie Steinbock, Andrew Botterell, and Françoise Baylis for their comments on drafts of the chapter. I would also like to thank the Stem Cell Network, a member of the Networks of Centres of Excellence program, for support in the way of funding, and the Lupina Foundation for giving me a fellowship at the Munk Centre for International Studies (University of Toronto), which gave me much-needed time to write the chapter. In many ways, this chapter is a companion piece to a paper I co-wrote with Francoise Baylis (McLeod and Baylis 2006). One section of this chapter, namely 'On Commodification and Alienability', is a version of what appears in that other paper. 
show For Love or Money (which is the inspiration for the title of this chapter), think again. The premise of the show is more real than it may first appear. If, unlike most undergraduate students in North America, you have never seen the show and think the above question might be an idle academic one, think again also. Love-for men, for children, or for themselves-has often been something women could choose only if they were willing to sacrifice their financial independence. Good women put their partners' careers first and do not pursue demanding careers if they have small children at home. Good women, dignified women, also do not sell their sexual or reproductive services (e.g. by becoming prostitutes or contract pregnant women), even if doing so could get them out of poverty or serious debt. For women, being 'for money' has often meant being against love or dignity.

The dilemma of dignity or money presents itself to women in new ways in the current age of technological reproduction. In some legal jurisdictions, ${ }^{1}$ women can now sell forms of reproductive labour that in the past were non-existent: they can undergo oocyte retrieval for the purpose of selling oocytes, or they can engage in commercial, gestational contract pregnancy. Oocyte vendors respond to a demand for oocytes used in treating some forms of female infertility, or for research, particularly human embryo research done on embryos that are created for the research itself (which would include some embryonic stem cell research). As oocyte vendors, women commit themselves to performing the laborious task of oocyte retrieval, and consent to use this reproductive labour not for their direct reproductive benefit, but for the reproductive benefit of others, as women do with contract pregnancy. ${ }^{2}$. While women who sell such labour may get healthy sums of money in return, they also may sacrifice their dignity as women. Traditionally at least, dignified women did not treat their reproductive potential as a source of cash.

At issue here is the moral permissibility of commodifying women's reproductive labour, particularly given the double bind, or binds, that such commodification poses for women. Should women be able to treat their own reproductive labour as a commodity, that is, as something that can be traded for a price? Should others encourage them to do so, despite the difficulty many women would find in choosing whether to sell such labour? Assuming that ethical restrictions exist on what things can properly be commodified, it is an open question whether women's reproductive labour is among these things. This question is both open and difficult, for a number of reasons. For example, while the financial independence that the selling of such labour could offer women is in some sense empowering, the work

sock, Andrew , like to thank or support in nk Centre for e the chapter. vylis (McLeod nability', is a

\footnotetext{
1 These include many states in the United States, but exclude, for example, all areas of Canada, Britain, France, and Australia.

2 Following Donna Dickenson (2001: 211), I assume that when women sell or donate oocytes or embryos, they are engaged in a form of labour, since the oocyte retrieval process involves mental or physical exertion as well as physical pain on the woman's part (see below for a description of this process). Labour is simply the 'exertion of the faculties of the body or mind, especially when painful or compulsory' (Oxford English Dictionary online).
} 
itself seems to be degrading. Feminists need to sort through such difficulties, and do it soon, because of the growing market in, and the growing pressure on women to provide, reproductive service through oocyte vending and commercial contract pregnancy.

Some feminists have tried to provide answers to this problem; but unfortunately, their answers tend to conflict. Whether the subject is oocyte vending or commercial contract pregnancy, some feminists argue that being able to sell reproductive labour is empowering for women in general (i.e. not just financially); to deny women this right would be to treat them in a manner that is inconsistent with their status as autonomous persons. By contrast, other feminists claim that allowing women to sell reproductive labour is degrading, and hence ultimately disempowering, for women. The debate is reminiscent of feminist debates about pornography and prostitution. Are oocyte vending and commercial contract pregnancy reproductively liberating for women, just as pornography and prostitution are sexually liberating for women, according to some feminists (Vance 1984)? Or is the liberation really just disguised subordination? For ease of exposition, and borrowing some terminology from For Love or Money, I will say that those who claim the former are for money or in favour of commodification, which may or may not be compatible with being for dignity (i.e. women's dignity) or against women's subordination.

My main purpose in this chapter is to lay out the 'for money' and 'for dignity' arguments that feminist ethicists have given about the reproductive labour women perform in providing oocytes or in getting pregnant for others. ${ }^{3}$ Feminist arguments about the morality of these two practices overlap significantly because, from a feminist perspective, the morally relevant facts about them are quite similar. Still, there are dissimilarities, stemming from the obvious fact that one practice involves giving up oocytes while the other involves giving up a baby after a pregnancy (Steinbock 2004: 255). Some arguments by feminists reflect this core difference, in that they apply specifically to one practice but not to the other. I shall highlight when the relevance of a particular argument differs for these different reproductive practices.

The structure of the chapter is as follows. I begin with a discussion of the meaning of 'commodification' and of a related term, 'alienability', followed by a description of the commodification of women's labour in providing oocytes and in undergoing contract pregnancies. I then elaborate on why having to choose dignity or money with respect to such labour is a double bind for women. In the next part of the chapter, which is the bulk of it, I explain how feminists have dealt with this dilemma of dignity or money. The chapter ends with a summary of the state of the feminist literature on this topic, along with recommendations for future feminist inquiry.

\footnotetext{
${ }^{3}$ My exposition covers only the feminist literature, and thus excludes such non-feminist arguments as religious arguments against 'sinful' uses of one's reproductive capacity (see Steinbock 2004: 256).
} 


\begin{abstract}
ulties, and
in women

1 contract

On Commodification and Alienability

To begin: when exactly is women's reproductive labour commodified? And is commodifying it a bad thing, given the nature of commodification? In other words, is commodification inherently bad? It turns out that commodification can be, morally speaking, malign or benign. Whether one commodifies something malignly depends in part on whether that thing is normatively alienable to persons (or to other beings with moral worth). Something is alienable to us if it is separable from us; and something is normatively (or benignly) alienable to us if it is separable without causing us harm or degradation. When we treat something that we possess as a commodity, we treat it as an 'item of trade' (OED), that is, as something that we can trade away and therefore separate from ourselves, to some degree at least. But we cannot separate everything from ourselves and remain intact as persons; therefore, we cannot commodify everything benignly. Understanding commodification and alienability, and how they connect up with one another, is crucial for navigating smoothly through the ethical debate on commodifying women's reproductive labour.
\end{abstract}

\title{
Commodification
}

First consider commodification: when we commodify something, we 'take that which is not already a commodity and make it into, or treat it as though it were, a commodity. Simple enough, but what the heck is a commodity?' (McLeod and Baylis 2006: 3). Marx (1867/1954: 43) wrote that 'A commodity is, in the first place, an object outside us, a thing that by its properties satisfies human wants of some sort or another.' The satisfaction of human wants is the use value of the commodity for Marx. As he notes, however, something can have use value without its being a commodity. For example, I might (poorly) design a coat and only wear it myself, to satisfy my desire for warmth, rather than sell it or trade it. In that case, the coat is not a commodity. 'To become a commodity a product must be transferred to another, whom it will serve as a use-value, by means of an exchange' (Marx 1867/1954: 48). In other words, a commodity is fundamentally an item of trade. As such, it has exchange value as well as use value.

In his description of commodities, Marx (1867/1954: 43-87) speaks of commodities as though they were essentially objects, which is not obviously the case. Arguably, a service can be a commodity, and a service is not an object. With some services, the true commodity may just be the product of the service (e.g. a clean house in the case of cleaning as a service); but with other services, such as reproductive services, there may be no product in the end (i.e. no baby or no oocyte), yet the person who performs the service may be compensated nonetheless, which suggests that the service itself is a commodity. For example, some women 
who enter into contract pregnancies are remunerated to some degree for their reproductive service even if the pregnancy ends in a miscarriage or a stillbirth.

Thus, a commodity is an object or service that one trades for something of equal value, typically money. To commodify something, then, is typically to turn it into, or treat it as though it were, an object or service that one trades for a price. As Margaret Radin (1996) emphasizes, this process can be complete or incomplete; one can commodify something only to a degree.

Commodification can also be morally benign or malign (not unlike objectification; see Nussbaum 1995). Relevant factors in determining moral permissibility with commodification include the following: (1) 'whether the thing commodified has intrinsic value that is incompatible with its being' treated as a commodity, where an example might be a religious artifact; (2) 'whether moral constraints exist on the alienability of the thing from persons,' as they do in the case of lifesustaining organs; (3) 'whether the consequences of making the thing alienable and of commodifying it are' unfavourable, which may be true for non-life-sustaining organs, such as second kidneys (McLeod and Baylis 2006: 3). (2) and (3) both concern (normative) alienability, which is the focus of the feminist literature on the permissibility of commodifying women's reproductive labour. ${ }^{4}$ Should the labour be commodified, given that women will have to alienate it from themselves, along with the products of their labour?

\section{Alienability}

Alienability is related to commodification in that it shapes whether the latter is benign, as illustrated above. A legitimate commodity is an object or service that is normatively alienable to persons, meaning they could transfer or forfeit it without doing damage to their selves (Radin 1996: 17; Bartky 1990: 34). For example, people can transfer their savings into mutual funds without harming or degrading themselves. Yet they cannot exchange for money the protection afforded by their basic human rights without causing such harm.

Alienating something from the self that is not normatively alienable to it brings on a state of alienation. Here, the self is so fragmented from what is constitutive of it that it cannot be itself, cannot be psychologically integrated, or cannot be truly human. Marx thought that alienation occurs when workers are forced to engage in productive activity that is neither free nor creative. Doing the opposite of such activity - that is, doing truly stimulating and imaginative work-was definitive of humanity for Marx (1844/1964).

4 (1) applies to whether the products of this labour (i.e. oocytes, embryos, fetuses, and babies) have such intrinsic value that they should not be commodified, which relates directly to the commodification of them, as opposed to the labour that goes into creating them. This chapter deals only with issues that
directly concern the latter. 
for their

rth.

of equal 1 it into, rice. As implete;

jectificssibility odified nodity, straints of lifesle and aining i) both on the labour along

ter is hat is thout nple, Iding their ings re of ruly Jage iuch e of

In the Western philosophical tradition, our humanity resides primarily in our autonomous agency, and in what sustains that agency, although what does sustain it is a subject of considerable controversy. Feminists tend to disagree with mainstream moral theorists on this point about sustainability; they tend to define autonomous agents as more relational (i.e. sociopolitically constituted), more embodied, and more emotional than non-feminists do (Mackenzie and Stoljar 2000). What might count, therefore, as benign commodification based on what is normatively alienable to persons may differ for feminists compared with non-feminists. As we shall see, some feminists base their moral analyses of the commodification of women's reproductive labour on feminist accounts of autonomous agency, and, more specifically, on whether women can maintain their autonomy, or personhood, while separating themselves from the emotional and embodied aspects of their labour.

\section{The Reality of 'Dignity or Money' With ReSPECT TO WOMEN's RePRoductive LAB OUR}

Before turning to feminist arguments in favour of dignity or money, we should be clear on what the facts are concerning real practices of commodifying reproductive labour. What are the morally relevant facts, particularly from a feminist perspective? When women engage in oocyte vending or commercial contract pregnancy, what do they trade away, for what, why, under what conditions, and with what consequences to themselves?

First of all, what do women trade away? The most obvious answer perhaps, assuming that their labour fulfills its purpose, is, in the case of oocyte vending, their own oocytes, and in the case of contract pregnancy, a baby that is their own in the sense that they gestated the baby (and would also be genetically related to it if their contract pregnancy were traditional or genetic, as opposed to gestational). But women also give away a lot of their own sweat and, possibly, tears when they perform reproductive labour for others. Even to get chosen in the first place to do such labour, women have to fill out forms that can be longer 'than college applications' (J. Cohen 2002); and they often have to undergo a series of medical tests, including psychological tests to rule out mental health problems (McShane 1996: 32; Serafini et al. 1996: 38, 39). The serious work begins, however, only if they succeed in getting chosen: they must have oocytes retrieved in the case of oocyte vending, or get pregnant, carry the pregnancy to term, and deliver a baby in the case of contract pregnancy. The process of oocyte retrieval involves uncomfortable daily hormone injections, frequent blood tests and ultrasound examinations, and 
the often painful procedure of retrieving the eggs, which proceeds by laparoscopy or vaginal ultrasound normally while the woman is under partial sedation (see Fielding et al. 1998: 274; New York State Task Force 2002). Gestational contract pregnancy includes weeks of hormone injections, as well as uncomfortable tests to assess potential blockage in Fallopian tubes, and the sometimes painful procedure
of embryo transfer.

What do women get in exchange for this labour? Aside from possibly feeling good about themselves for helping others, they can receive large sums of money. With oocyte vending, the going rate is anywhere from $\$ 1,500$ to $\$ 5,000$ in the United States, if the women are paid only for their 'time, effort, and discomfort' (New York State Task Force 2002). Yet sometimes the women are paid also for their oocytes, that is, if they provide them to couples who want a 'designer baby': often one who is intelligent, musical, and good-looking. Some of these couples are willing to pay thousands of dollars for oocytes (e.g. $\$ 50,000$ ), at least according to advertisements in Ivy League college newspapers (Steinbock 2004: 259). Such payments resemble those given for gestational contract pregnancy, for which payments tend to run between $\$ 18,000$ and $\$ 25,000$ (again in the United States). ${ }^{5}$

Why do women perform the labour? Do they just really need the money? In general, women who vend their services of oocyte retrieval and pregnancy are not desperate for the money, although they could certainly use it. Oocyte vendors and contract pregnant women tend to be less well off financially than the couples who pay them. Sometimes, they are in university and face the prospect of large student debts. But often they are working class women, with little to no postsecondary education, who have children of their own to support (Fielding et al. 1998: 276; Ragone 1994: 54-5). Many reproductive labourers say that financial reward is an important consideration, but not their primary motive for performing the relevant service (Ragone 1994: 57; 1999: 78). More often than not, they want to do what they are doing because it helps people or because, in the case of contract pregnancy in particular, it makes them feel special (perhaps because they get to be pregnant, and being pregnant is special) (Anderson 1993: 180). ${ }^{6}$

Under what conditions are women performing this labour? Usually, with oocyte vending and contract pregnancy, a power differential exists between relevant parties, which does not favour the woman as reproductive labourer. The differential can be based on gender, class, or race. For example, traditional or genetic contract pregnancies often occur against a background of gender- and class-based inequalities,

${ }^{5}$ Source: David Smotrich, reproductive endocrinologist and medical director of La Jolla IVF in Sar Diego, California; personal communication, 2 Oct. 2004 . These amounts are what contract pregnant
women get paid only if they produce a baby in the end.

6 Other possible reasons include, with oocyte vending, wanting 'to know if [one's] eggs are "good"'
Steinbock 2004: 258), and, with contract pregnis. (Steinbock 2004: 258), and, with contract pregnancy, seeking to resolve guilt feelings about a past
abortion (Anderson 1993: 180), presumably by carrying its life. 
laparoscopy

:dation (see

ral contract

able tests to

I procedure

seling good

sney. With

the United

(New York

ir oocytes,

$\mathrm{n}$ one who

ing to pay

rtisements

i resemble

ad to run

toney? In

y are not

idors and

ples who

a student

scondary

198: 276;

ard is an

relevant

do what

egnancy

segnant,

oocyte

parties,

I can be

t preg-

ralities,

$F$ in $S a n$

rregnant

'good"'

$\mathrm{t}$ a past

ending since the contracts exist between the sperm provider, a man who is usually well off, and the contract pregnant woman, who is usually not so well off. With gestational contract pregnancy, racial inequality can occur, and in a way that benefits the paying couple, because of racial differences between them and the woman who bears a child for them (see Ragone 2000: 65-6). Such inequalities may not at all compromise the moral legitimacy of these contracts; but they could do so because of how vulnerable they can make the reproductive labourer.

The conditions under which women exchange their reproductive labour for money can also involve manipulation or deception. Reproductive labourers are manipulated when information about the nature of the relevant medical procedures is withheld from them, and when the 'downstream commodification' (Holland 2001) of their labour is withheld. Recent studies show that withholding information about procedures (and consequently undermining informed choice) is common in oocyte 'donation' programs in the United States (Gurmankin 2001; New York State Task Force 1998). For instance, in preliminary attempts to gather information from many of these programs, prospective vendors will receive either no information about risks or inaccurate information (Gurmankin 2001). Often, they will not be told about the potential risk of ovarian cancer from the hormone injections, and about the risks of infertility or of ovarian hyperstimulation syndrome, which in severe cases is life-threatening (Fielding et al. 1998: 274; Serafini et al. 1996: 37). The motivation to manipulate or coerce women to sell their reproductive labour can be quite strong because of a shortage of 'desirable' labourers or simply because reproductive labour is big business for the intermediaries involved, that is, for those who run the programs. ${ }^{7}$ Enterprises in oocyte 'donation' are highly lucrative if the labour is commodified downstream from payment to the actual labourers (Mahoney 2000). Oocytes may be sold in this way to researchers or to infertile couples for significant profit, often without the woman who originally sold the oocytes knowing about that profit (Holland 2001: 266).

What are the consequences for women as reproductive labourers? In particular, what are the emotional consequences? Reportedly, they can include regret or shame for agreeing just to perform the labour or for agreeing to specific acts outlined in the contract (e.g. genetic abortion). For example, a woman might regret her consent to be an oocyte vendor after she discovers how painful the process of retrieval can be. ${ }^{8}$ A woman who serves as a contract pregnant woman might wish that she had never consented to abort her pregnancy if the fetus has a genetic abnormality, to reduce her pregnancy selectively if it is a multiple one, or just to give 'her' child away.' Of course, not all women who sell or donate their reproductive labour experience

\footnotetext{
7 See J. Cohen (2002) and Ragone (2000:61) on the difficulties that couples can have with finding the labourer they want.

A student of mine had that experience.

9 Consents to both genetic abortions and selective reductions are common in pregnancy contracts. Selective termination is an issue with gestational contract pregnancy, because multiple pregnancies are
} 

about doing it the first time. ${ }^{10}$

Women who respond to the market for reproductive labour can also experience rejection that threatens to undermine their dignity, or others' dignity. While troubling can reject a prospective labourer for reasons that are not morally a woman for reasons the woman's health is truly poor-they can also reject smart enough, or talented enough. Such - for example, she is not pretty enough, contests or college admissions, but they are andards may be appropriate for beauty determining whose gametes to use when cretingly inappropriate as standards for is that, in this context, the standards in creating a new human being. The reason gamete provider herself) were imply that some lives (including that of the

The abovemention

commercial contract facts suggest that in consenting to oocyte vending or just the physical act of reproductive might alienate from themselves more than owing to manipulation, some integrity labour. They might also lose some autonomy to rejection. Since such qualities are owing to regret, and some dignity owing loss is morally regrettable to say the least.

\section{The Double Bind of Choosing Dignity OR MONEY}

Given the negative impact that the market in reproductive labour can have on women, one might wonder why feminists are so divided about it. Why not just ban important, unless in did we be sacrificing if we did that? It has to be something track. On the contrary this issue, which is quit I think they are right on track in struggling so much with

In having to decide whether

ductive capacities, feminists to endorse the commodification of women's reprofeminists, they are damned if they allow the couble bind. In other words, as ductive labour and damned if they don'the commodification of women's reprowomen to be exploited, especilly if substan do the former, they risk allowing occurs. Exploitation is an iscially if substantial downstream commodification ticularly for poor or economically all potential reproductive labourers, but parcommon in such arrangements, since multiple embryos are transfered to the uterus of the contract
mother during the IVF process (Ragone 2000). 19) In one 
for oocyte retrieval or contract pregnancy irresistible. A further problem with commodification is that it would 'seem to treat [women's reproductive capacities] as... fungible market commodities', which 'in this culture... [could] diminish the personhood of women' (Radin 1991: 349). In other words, women could be objectified as breeders when their reproductive labour is commodified. Women may themselves go to market, as cows do.

But banning commodification would not obviously serve women's interests either. For one thing, being able to sell their reproductive labour gives women market power, which is power within capitalism. Yet women have 'historically been denied [this power]', and currently have a lot less of it than men, which suggests that barring women from it in the realm of reproduction could really harm women (Radin 1991: 349). In particular, it could harm poor women who might better their situation a lot by responding to the market for oocytes or for contract pregnancies. Sometimes, guidelines for the latter require 'that the candidates not be poor women who need the money' (Radin 2001: 309). Besides being paternalistic-perhaps 'in the worst way"11 since the paternalism involves wealthy people telling poor people what they cannot sell-such measures force poor women to 'remain in bad circumstances' (Alpers and Lo 1995: 42). They prohibit 'desperate exchanges' (Walzer 1983) because exchanges founded on the desperation of one party are wrong; but they do nothing to ease the desperation.

Moreover, if banning commodification meant encouraging more altruism (i.e. altruistic donation or contract pregnancy), then women would not necessarily benefit. Women have traditionally been the 'care-takers of the world' (Mahoney 2000: 188), which has probably brought them more toil and suffering than joy. Relying on women's acculturated desire to help others as a way to ensure that oocytes and babies are available to infertile people would simply perpetuate sexism.

Thus, various things that are bad from a feminist perspective could happen if we banned commodification, and if we did not. While a ban would do nothing to alleviate, and might even encourage, the disempowerment of many women, the absence of a ban leaves women open to exploitation and to breeder status.

This dilemma of dignity or money exists largely because of women's oppression. If women as a social group were not so oppressed that they were taught to be self-sacrificing nurturers, were excluded from powerful positions in the market economy, or were regularly forced into poverty upon divorce and becoming single mothers, the issue of commodification would not be so troubling for feminists. Oppression has this effect of creating double binds (Frye 1983); it keeps people down by ensuring that they repeatedly face choice situations in which the only available options are grim ones.

One might argue that rather than choose one side of the bind of dignity or money, we could simply work toward eliminating the oppression of women-that

11 Alta Charo put it to me this way in conversation. 
is, toward removing the conditions that create the bind. Do we not just promote women's oppression anyway if we accept the awful choice situations that it puts women in? Still, do we really have the choice not to respond to these situations? If, instead, we simply worked toward 'ideal justice' - that is, no oppression but rather real reproductive and economic freedom for women -we might miss the chance to create 'nonideal justice', or a situation that is at least more just than our current one. Radin calls this broad dilemma of ideal versus nonideal justice 'the double bind' (1996, ch. 9; my emphasis). Feminist activists come up against it all of the time, in having to balance 'their aspirations for a right world' with their ability to right some wrongs 'in the here and now' (Shultz 1990: 337).

Feminists who do embrace one side of the bind of whether to commodify women's reproductive labour are sensitive to varying degrees to the strength of this bind and to the need to fight against the oppression that causes it. Let me outline their arguments, starting with those that are for money.

\title{
FOR MONEY
}

Past feminist arguments for money focused on contract pregnancy (e.g. Shultz 1990; Shalev 1989), while present arguments deal mostly with oocyte vending (e.g. Mahoney 2000; O'Donnell 2000). Further, most of the arguments-past and present - apply equally well to both practices. Some of them are merely arguments for money, while others are arguments for both dignity and money-assuming that being for money is compatible with being in favour of women's dignity. (Who would admit to being against it?) I deal with the latter sort of arguments in the next section, and focus on the former here.

Arguments that are (merely) for money say that commodifying women's reproductive labour is preferable to the alternatives. And the alternatives include: (1) a system of donation that relies upon altruism; (2) being paternalistic toward women and telling them that they cannot perform reproductive labour for others at all; and (3) having a black market crop up in response to a ban on commodification. Arguments for money exist that address each of these possibilities.

\begin{abstract}
Altruism
Feminists for money claim that a commercialized system is preferable to an altruistic one, because the latter would prey upon the socialization of women as 'care-takers of the world' (Mahoney 2000: 188, 192; Shultz 1990: 380). Most programs for oocyte vending and contract motherhood prey upon this socialization process now. They weed out women who apply because of the money rather than the opportunity to help others in need. For women who do become 'donors' or
\end{abstract}


contract pregnant women, the programs tend to characterize the compensation they receive as 'reimbursement' rather than purchase (Mahoney 2000: 188), presumably to avoid the bad press the programs would get by admitting that they buy and sell women's reproductive labour. According to feminists for money, the programs should be buying and selling the labour, and be open about that fact, because otherwise they exploit women (especially if they profit themselves from downstream commodification), and they promote sexist stereotypes about women. On the second point, Julia Mahoney writes that, 'the implication that young women should desire to undergo a series of highly uncomfortable procedures that pose both short-term and long-term risks to their physical well-being for which they [may not or] will not collect the market clearing price threatens to reinforce stereotypes of females as generous rather than self-interested' (2000: 188; my emphasis on 'women').

The fact that we are asking women to be generous in this area is significant, given our history of relying on women to respond to others' needs, especially surrounding childbearing and -rearing; and given that we do not have similar expectations of men (for whose sperm we pay).

\section{Paternalism}

Some feminists would agree that we should not expect women to do reproductive work for free, especially when we pay men for much less arduous 'work' (as if masturbating in a cup was work!); but better yet, they would argue that we should not expect women to do the work at all. On their view, we should discourage women from becoming reproductive labourers because of how unlikely it is that women will choose to do so autonomously. Barriers to women's autonomy in this area lie in sexist norms about women, the nature of the relevant work (particularly with contract pregnancy), and poverty. For example, norms about women's worth residing in their reproductive potential, which could make a woman want to be pregnant even if she cannot keep the child she bears or even believe that the child is hers during the pregnancy (a common attitude amongst women in gestational contract pregnancies; Ragone 2000: 69), can profoundly shape a decision to undergo a contract pregnancy. Moreover, as some argue, entering into a contract to relinquish a child at birth before it has even been conceived is not something women can do freely, for they cannot predict how they will feel about a pregnancy once it occurs.

In response to these objections about autonomy, feminists for money say two things: first, such arguments give too little credit to women as autonomous agents, and, second, they reinforce stereotypes that women lack autonomy. In other words, the objections support a form of paternalism that is profoundly disrespectful of women. Women are not dupes in the face of pronatalism, according to these 
feminists; women can rationally weigh the risks and benefits of contract pregnancy and of oocyte vending, and critique their own reasons for wanting to do either. Similarly, with contract pregnancies, women can anticipate and factor into their decision-making possible shifts in their perceptions of their pregnancies, especially if they have been pregnant before, which is true of most contract pregnant women (Ragone 1994: 54). The opposite idea-that women cannot enter into pregnancy contracts because they might have a change of heart--encourages a view of women as 'unstable, as unable to make decisions and stick to them, and as necessarily vulnerable to their hormones and emotions' (Shultz 1990: 384). The worry that they will change their minds in favour of keeping a baby that they gestate in a contract pregnancy also reinforces the view that 'some kind of instinctive maternal bonding to the fetus' occurs in pregnancy, which would be true only if women were maternal by nature (Shalev 1989: 121). But since most feminists reject reproductive essentialism for women, they should also reject paternalistic stances toward contract pregnancy in general. Or so say feminists for money.

\section{Black Market}

In the view of these feminists, banning commodification would only lead to a black market in women's reproductive labour anyway, which could not be good for women. With a black market, there may be little incentive, if any, to ensure that women's participation is autonomous. There may instead be a strong incentive to coerce women into participating because of the ability either to reap large profits if one is an intermediary, or to get the oocyte vendor or contract pregnant woman of one's dreams if one is a buyer. Moreover, a black market would almost inevitably heighten inequalities in power between women, including class- and race-based inequalities. While it is true that what the market will bear would determine payment, surely classism and racism would shape what the market will bear. Lowerincome women of colour would be paid less than middle-income white women either because the latter's genes or wombs are deemed more desirable (because of classism and racism) or because the former may be desperate and take whatever money they can get. ${ }^{12}$ The net result of a ban on commodification, according to these feminists, is a situation that would be much worse than what we get with
commodification.

Feminists for money generally favour a regulated market in oocytes and contract pregnancies, compared to a black market or a system of donation. (Hence, what

12 With respect to oocytes specifically, Ann Alpers and Bernard Lo refer to a two-tiered market that may already exist: 'one high-priced market for the eggs of white middle-class women to be sold whose ova are valued for IVF treatment and another for the eggs of lower-income women of color to create embryos that will ultimately beses only' (1995: 42). In the latter case, the ova may be used getting a relatively low price for one's oocytes. 
they actually endorse is incomplete commodification. One does not commodify anything completely if one regulates the market for it. With regulation, non-market values are at play determining what the regulations are, which in turn limit property rights in the commodified item or service.) Feminists for money also tend to believe that regulation could solve many of the problems that people often see with commodification. For example, governments or medical associations could impose a cap on payments for reproductive labour so that no group of women gets considerably more than any other group and no woman finds the payments irresistible. The American Society of Reproductive Medicine already recommends a cap of $\$ 5,000$ (an amount that may be too high) on compensation for oocyte 'donation' (ASRM 2000). In addition to policies that concern payment, we could have ones about informed choice that ensure oocyte vendors and contract pregnant women are always free, informed, and competent. The process of informed choice for either practice could always occur in the presence of a feminist counsellor even, who would be attuned to how pronatalist norms can (but do not necessarily or even frequently!) undermine autonomy for women in reproductive choice situations. With policies like these in place, women who are reproductive labourers would not be disempowered breeders. They would not be the handmaids of Margaret Atwood's Handmaid's Tale (1985).

We have seen that a regulated market in women's reproductive labour is preferable to various alternatives, according to feminists for money. We will now see that they defend such a market as well because it is a good or a just option, rather than simply the best amongst a host of possibly bad or mediocre options.

\section{For DIgNity AND MONEY}

Feminists for money assert that receiving payment for reproductive labour is dignifying for women for three main reasons. ${ }^{13}$ (1) Within capitalism, being paid to do things for other people is a sign of respect. (2) Getting paid to do reproductive labour for others can also enhance women's autonomy by fulfilling autonomous desires they may have to sell that labour. (3) Such payment disrupts patriarchal ideals of motherhood or womanhood. Let me deal with each of these points in turn.

\section{Respect}

Financial compensation and respect are intimately connected, whether the person who receives the compensation desires it or not (Shultz 1990: 336; Mahoney

13 These feminists are therefore for dignity and money; but since they are the same feminists as those who we were just discussing, for simplicity's sake, I will continue to refer to them as 'feminists for money.' 
2000: 205). While according to one strand of thought, monetary exchanges are less valuable than gift exchanges, 'In fact, there is a strongly competing truism suggesting that that which we reward with money is that which we value. In particular, the inability of women to gain monetary recognition for the things they uniquely or preeminently do is one of the core causal factors in the exploitation of women' (Shultz 1990: 336).

Paying for things suggests that we value them; but more to the point, paying people for what they do for us can show that we acknowledge them not as mere instruments for our use, but as people. Not paying others, especially when we reap substantial profits from their work (as some programs or clinics do that facilitate oocyte 'donations' or contract pregnancies) is exploitative. Marjorie Shultz implies that women are already exploited in many of the things they do for others. On her view, we should avoid adding reproductive labour to the list.

\section{Autonomy}

We should also respect the autonomy of women who freely agree to relinquish their oocytes for a price or to bear a child for someone else, according to feminists for money. We should do so because women's dignity demands it, not only because the alternative of being paternalistic is bad. Permitting the commodification of reproductive labour acknowledges that women can do what they want with their lives and with their bodies. Some theorists frame the moral issue of commodification as an issue of respect specifically for women's bodily autonomy. Richard Arneson writes that 'legal toleration of surrogacy presupposes that the woman's body is hers and hers alone unless she consents to some particular use of it' (1992: 162). In other words, if reproductive labour is commodified so that the women who perform it get to trade it for money, women's bodies must be their own. Donna Dickenson (2001) and Kath O'Donnell (2000) make the same sort of claim but in the reverse: women's bodies will be their own if we grant them some sort of property right in their bodies. Such a right would give reproductive labourers some control over who profits from their labour and some ability to protect themselves from exploitation. Whichever way they put the point, a strong connection exists for these feminists between commodifying reproductive labour and viewing women as the rulers of their own bodies specifically, and of their own fates more generally.

\section{Disrupting Patriarchal Ideals}

Finally, we honour women's dignity by paying them for reproductive labour performed for others, in the view of feminists for money, because payment, especially for contract pregnancy, helps to dismantle patriarchal ideals of motherhood and womanhood that are undignifying for women. According to these ideals, women 
undergo the 'emotionally volatile condition' of pregnancy (Shalev 1989: 121) for its own sake or in order to feel fulfilled as women. While pregnant, they develop 'sacred bonds' (Chesler 1988) with their unborn children that make it impossible for them to be separated from their children upon birth and for many years to come. Thus, with gestation comes motherhood, whether the pregnant woman intended to be a mother or not. In stark contrast to this picture, we have the practice of commercial contract pregnancy, in which women rationally choose to enter into and then honour a contract to bear a child for someone else in exchange for money, and not for mere feminine fulfillment. The contract pregnant woman acts rationally and need not bond so emotionally with her unborn child that she could not imagine life without it. (Gestation, therefore, does not entail motherhood.) Moreover, the mother of the child in the end (i.e. if the child is to have a mother, as opposed to one or two fathers) will not be the person who gave birth to it, but rather someone who paid someone else to give birth to it. Clearly then, with contract pregnancy, especially of the commercial variety, motherhood and womanhood cannot be what they are under patriarchy. For example, the 'standard of motherhood' must be 'intent-based' as opposed to gestational (Anderson 1993: 183), which is as it should be according to Shultz and Carmel Shalev. A parent of a child should be someone who intended to raise that child, or to bring him or her into existence. Shultz and Shalev object to the gestational standard because it does not allow women the dignity to choose their own life path. It binds women to children in circumstances in which women did not intend to be mothers, which is true of women in contract pregnancies and in unwanted pregnancies.

Thus, feminists for money suggest that women not only maintain the level of dignity they currently have, but in fact gain some dignity when their reproductive labour is commodified. If commercial reproduction were normalized, less of a connection would exist in people's minds between women's reproductive activity and motherhood. The end result would be tangible freedom for women to pursue goals other than becoming a mother. While this outcome would benefit all women, the actual compensation for reproductive labourers would support them specificaliy. It would show respect for these women as subjects rather than objects to be used by others, and as autonomous beings, assuming that they autonomously choose to sell their labour.

\section{For Dignity}

Underlying feminist arguments for money is the belief that we should deal with women's reproductive labour as we do other forms of labour for which a market exists (e.g. university teaching, rough carpentry). As with other labour markets, the reproductive one should be regulated to prevent discrimination as well as forced or 
coerced labour. People who respond to that market by offering their reproductive services to others should be paid what the market will bear and what the relevant regulations will allow, according to feminists for money. To put a label on their view, these feminists defend a 'symmetry thesis' with respect to women's reproductive labour: our treatment of it should be symmetrical with our treatment of other forms of labour. ${ }^{14}$ Feminists for dignity (alone) defend instead an asymmetry thesis. They contend that women's reproductive labour is special, in that, unlike other forms of labour, no one should sell it, nor consent to perform it for others for free perhaps. The labour is special either because of inherent features of it, which is the view of some feminists for dignity, or because of contingent features that exist when the labour is performed in environments that oppress women, which is Satz's (1992) view.

\section{The Labour Is Inherently Special}

So some arguments for dignity (alone), or against the commodification of women's reproductive labour, say that because of inherent features of such labour, the commodification of it is always malign. Let me consider two such arguments. One defends what I will call the 'identity thesis': that because a woman's reproductive activity is so intimately tied to her identity, it can never be an item of trade. The other argument, which is relevant only to contract pregnancy, concerns a thesis that I discussed earlier: that a woman's autonomous perspective on her pregnancy may evolve in such a way that she could no longer perceive the child within her as one that belongs to someone else; and the possibility that such a shift in perspective will occur suggests that she should not treat pregnancy as labour like any other form of labour. Let me call this thesis the 'autonomy thesis'.

\section{The Identity Thesis}

According to the identity thesis, reproductive activity is tied to the identity of women either as women or as persons. Feminists have used versions of this thesis to object first to contract pregnancy and then to oocyte vending and embryo donation. For example, Carole Pateman is described as asserting, in opposition to contract pregnancy, that 'a woman's self is intimately connected to her body in its reproductive function' (Arneson 1992: 161; Pateman 1988). A woman's identity as a woman is so tied to her reproductive activity, according to Pateman, that when she sells it, she 'sell[s] herself in a very real sense' (1988: 207; Satz 1992: 114). More recently, some feminists have stated, mostly in response to the growing market in oocytes and embryos, that women's identity as persons is tied

${ }^{14}$ This terminology is from Debra Satz (1992). She explores in her paper whether the opposite thesis, the asymmetry one, is true. She also discusses how feminists are split on the issue of symmetry
or asymmetry. 
to their reproductive activity or to their reproductive bodily tissues, including oocytes and embryos. For example, Radin suggests that reproductive activity is not a 'severable fungible object', but an essential attribute of persons (1996: 127). Suzanne Holland maintains that gametes and embryos have such 'an intimate connection to [our] personhood' (2001: 265) that they are inalienable from us and are therefore non-commodifiable (see also C. Cohen 1999). Notice that if reproductive tissues or activity are inalienable to us, not only should they not be sold, they also should not be donated to others. The identity thesis rejects both donation and vending.

Unfortunately, feminist claims about identity and women's reproductive activity or tissues tend to lack sufficient argument. Sometimes feminists take the claims to be sufficiently obvious that they are stated without argument, as they are in Pateman and Radin. At other times, the arguments that feminists provide are deeply flawed. For example, Holland defends her version of the identity thesis by saying that gametes and embryos have a special connection to us as persons because they are parts of our bodies, which themselves are 'intimately connected to ... who we are' (2001:273). Just as we should not be treated as mere commodities, our gametes and embryos should not either. The flaws in this argument are serious. They include not distinguishing body parts that are somehow essential to persons from those that are not (surely 'spit and fingernail parings' do not count; C. Cohen 1999: 291), and failing to defend the view that gametes and embryos in particular are essential to persons.

Feminist claims about why our reproductive activities or parts are inalienable to us tend to be not only unsound, but also pronatalist. If a woman's identity is intimately connected to her reproductive potential, then she can never escape her fertility. On the contrary, she should embrace it and discover part of who she is by actualizing her reproductive potential (McLeod and Baylis 2006). But such a conclusion supports the status quo, according to which women and men (but women in particular) are not free to lead a life in which reproduction does not occur, or is a non-issue. Satz made this sort of objection against Pateman's work in the early 1990s. Since then, feminists such as Holland and Radin have simply reproduced Pateman's mistake.

\section{The Autonomy Thesis}

A further attempt to establish that women's reproductive labour, particularly in pregnancy, is inherently different from other forms of labour concerns the need to restrict the autonomy of contract pregnant women to ensure that they maintain a certain relationship to their 'product' (the child): that is, a non-parental relationship. Women in contract pregnancies will have to manipulate themselves, or be manipulated by others, into having, or continuing to have, a perspective on their labour that fits with their contractual obligations; otherwise, a couple will lose their child. Either contracts for other forms of labour (at least for morally legitimate forms) do not require for their fulfillment the same degree of control over the 
labourer's perspective on what he is doing, or what's at stake with their fulfillment is not important enough to warrant profound manipulation. It follows that the asymmetry thesis is true. Elizabeth Anderson makes this sort of argument in 'Is Women's Labor a Commodity?' (1993). She explains that a woman in a contract pregnancy must agree at the outset not to view her pregnancy relationship as a parental one, which the woman may well do. But,

Regardless of her initial state of mind, she is not free, once she enters the contract, to develop an autonomous perspective on her relationship with her child. She is contractually bound to manipulate her emotions to agree with the interests of the adoptive parents. Few things reach deeper into the self than a parent's evolving relationship with her own child. Laying claim to the course of this relationship in virtue of a cash payment constitutes a severe violation of the mother's personhood and a denial of her autonomy. (Anderson 1993: 178)

As noted above, according to feminists for money, this line of argument itself denies women's autonomy by suggesting that their minds waver too much in pregnancy for them to enter into pregnancy contracts, or by implying that 'sacred bonds' inevitably develop during pregnancy.

But there are responses that feminists for dignity could give to these objections. First, changing one's mind about a decision at some point during a nine-month period does not indicate a lack of autonomy, since people who are autonomous will in fact reevaluate and often revise their decisions. Thus, a true autonomy thesis would respect a change of heart by a woman in a contract pregnancy. Second, it could do so while acknowledging that not all women bond with their fetuses. ('Some women abort them,' as Satz reminds us; 1992: 117.) Feminists could construct the autonomy thesis so that it says only that a woman may bond with her fetus, not because of some gender-wide instinct, but because she has cared for this being for months at a time. And whether a woman will bond with her fetus is not something of which she can be certain ahead of time, since women's perspectives on their pregnancies do tend to evolve as their pregnancies progress, and the evolution need not occur in the same direction as previous pregnancies (see Mackenzie 1992). Further, when bonding does occur, it can reach so deeply into the self that forcing the woman to relinquish the child would be cruel.

This autonomy thesis is weaker than Anderson's, however (which assumes that the pregnancy relationship will reach deeply into the woman's self); and it is not clear whether or not this weaker thesis supports the asymmetry thesis. Unless most pregnancy contracts required for their fulfillment that the labourer's perspective on her labour be seriously manipulated (which would be the case only if sacred bonds were inevitable), such manipulation would not need to be common practice. And therefore perhaps the labour, in this respect, would not have to be treated differently from other (legitimate) forms of labour. But even though manipulation may not need to be common, one might argue that it would have to occur in some cases and it would not be known ahead of time which cases (i.e. if the weaker autonomy thesis were true), which itself could make pregnancy contracts unique and morally 
problematic. In other words, perhaps the weaker thesis does support the asymmetry thesis.

\section{The Labour Is Contingently Special}

Satz maintains that both the autonomy thesis and the identity thesis are totally indefensible. Nevertheless, she contends that an asymmetry exists between women's reproductive labour and other forms of labour. For Satz the asymmetry is contingent upon the reproductive labour being performed in an environment that is sexist, racist, and classist.

Satz's main criticism of pregnancy contracts is that they strengthen gender inequality. They feed on an environment in which women earn significantly less than men, live in poverty more often than men, are more confined to the home because of an unequal distribution of child care and other domestic work, and, in general, have less opportunity to better their lives (1992: 124). Gender inequality extends as well to reproduction, where men have historically had more control than women over when, and how, women reproduce. Contract pregnancy reproduces this pattern by having women relinquish significant control to others (sometimes specifically to men) over their own bodies in pregnancy (Satz 1992: 124, 125). The practice is troubling for this reason, and because it reinforces a pronatalist connection between women and reproduction, and a further connection between women and the home, since women in contract pregnancies tend to stay at home. Satz claims that while some women may prefer to be at home and to make money by selling their reproductive labour, 'we need to pay attention to the limited range of economic opportunities available to these women and to the ways in which these opportunities have shaped their preferences' (1992: 127).

For Satz, contract pregnancy involves increased subordination rather than autonomy for women, in addition, because it shores up rather than dismantles the core foundation of parenthood under patriarchy, which is genetic rather than gestational. With a genetic standard for parenthood, men are at least equal parents to women, although, traditionally, their 'seed' meant more than a woman's in defining whose child a particular child was. Women were simply 'the incubators of men's seeds' (Satz 1992: 128). On the genetic model, gestation does little to shape whom a child will become, although it may do a lot to determine how a woman will feel toward that child. Women are mostly just the 'maternal environment' during pregnancy; and if their genes were no part of the fertilization process, then they are no parent at all. In settling disputes about pregnancy contracts, the courts in the United States have supported this picture; they will grant parental rights to a woman who bore a child as a result of a genetic (or traditional) contract pregnancy, but not as a result of a gestational contract pregnancy (Satz 1992: 127). 
Satz concludes that the loss of dignity for women is profound, but not inevitable with contract pregnancy. Many of us recall images of women as incubators or breeders when we contemplate this practice, and for good reason, according to Satz. Contract pregnancy reinforces sexist stereotypes that prescribe undignified social roles for women. But if these stereotypes did not exist-that is, if our society were nonsexist - the practice would be more benign, morally speaking, in Satz's view. It may not be cómpletely benign, only because it could still flourish as a result of inequalities that are class- or race-based, rather than gender-based (Satz 1992: 128, 129). ${ }^{15}$

\section{Moving Forward}

In broad summary, most feminists who are for dignity alone - that is, against commodification - are at the opposite pole of feminists who are for money, or in favour of commodification. Whereas the latter say, 'Pay the women, not only because it is the best option given the circumstances (of poverty for women etc.), but because it is the most dignified option for women', the former assert that it is simply undignified for women to sell their reproductive labour: they sacrifice too much of their identity or their autonomy in doing so. With her work on contract pregnancy, Satz is somewhere in between these two poles, for she claims that selling reproductive labour could be dignified, or at least not undignified, in an egalitarian society. Satz's work is important because it cautions against the reproductive essentialism that is embedded in some feminist claims about women's reproductive labour being inherently special. In discussing how contract pregnancy promotes gender inequality, Satz also exposes the naivety of some feminists for money in thinking that this practice could actually liberate women.

Still, it is not clear that Satz responds adequately to the double bind of dignity or money that I outlined earlier. She says that we should discourage pregnancy contracts by making them legally unenforceable, for example (1992: 129), which is the logical conclusion to her argument. But, on its own, this solution does little to address the limited range of economic opportunities available to (women for whom the contracts are attractive]' (Satz 1992: 127), a range that Satz herself identifies. Are we justified in restricting this range, so that it excludes reproductive labour, while doing nothing to expand it? If not, could our plans be for long-term expansion alone, or would we have to introduce some short-term relief in exchange for eliminating the opportunity of selling one's reproductive potential? Further, how serious is the risk of a black market arising in which female reproductive

\footnotetext{
15 A refusal to grant parental rights to a woman who underwent a gestational contract pregnancy because she lacked a genetic tie to the child (children in fact, since there were twins) has occurred in
Canada as well; see I.R.v. L.H., [2002] OJ 3998 (QL).
} 
Ible

ed-

on-

les

sn-

\section{$\ldots$}

labourers have even less dignity than they do now? Feminists need to address these practical matters, or, in other words, confront head on the main oppressive aspect of commodification: that it creates a double bind for women.

Moving forward with the feminist debate on commodification will also require that feminists learn from what other feminists, or non-feminists, have written on topics similar to their own. Even amongst feminists writing on women's reproductive labour, there has been little cross-pollination of ideas. The newer debate on oocyte vending does not respond well to progress in the older debate on contract pregnancy. For example, just as reproduction should not be seen as inherent to women's identities, perhaps neither should oocytes or embryos. But if that is true, the question remains whether oocyte vending is morally problematic; and if it is problematic, is the problem contingent on the practice occurring in certain sociopolitical environments, or is it inherent to the practice itself?

Feminists writing on oocyte vending or commercial contract pregnancy could also draw valuable insights from feminists who have theorized not about these practices, but about others that raise similar moral issues for feminists. For example, feminists have done detailed work on what it means to say that women are autonomous in choosing cosmetic surgery (Morgan 1991) or medical interventions in pregnancy (Sherwin 1998; McLeod 2002). They have discussed how myths of beauty or of pronatalism can shape women's preferences for these interventions such that the preferences are not fully autonomous, but may be rational nonetheless given how much easier it is to get by in a sexist world if one conforms to its expectations. Such subtle distinctions - for example, between autonomy and rationality (or a form of rationality) - are important for any nuanced discussion of the autonomy of women who engage in gendered pursuits such as selling their reproductive labour.

Thus, while feminist debate on commodifying women's reproductive labour is surely intricate, there is room for even more depth and sophistication. In particular, the debate could progress more toward concrete solutions that genuinely promote women's autonomy if the situation of potential reproductive labourers was analogized with that of potential consumers of cosmetic surgery, for example, or potential sex trade workers. The promise of such a turn in the literature is a greater appreciation of how choosing between dignity and money with respect to women's reproductive labour is a classic double bind.

\section{REFERENCES}

Alpers, A., and Lo, B. (1995), 'Commodification and Commercialization in Human Embryo Research', Stanford Law and Policy Review, 6/2:39-46.

ANDERson, E. S. (1993), 'Is Women's Labor a Commodity?', in Anderson, Value in Ethics and Economics (Cambridge, Mass.: Harvard University Press), 168-89; first pub. in Philosophy and Public Affairs, 19/1 (1990), 71-92. 

Arneson, R. J. (1992), 'Commodification and Commercial Surrogacy', Philosophy and
Public Affairs, 21/2: 132-64.

ASRM (American Society of Reproductive Medicine), Ethics Committee (2000), 'Financial Incentives in Recruitment of Oocyte Donors', Fertility and Sterility, 74/2:
$216-20$.

Atwood, M. (1985), The Handmaid's Tale (Toronto: McClelland \& Stewart).

BartKY, S. L. (1990), 'Narcissism, Femininity, and Alienation', in Bartky, Femininity and Domination: Studies in the Phenomenology of Oppression (New York: Routledge), 33-44.

Chesler, P. (1988), Sacred Bond: The Legacy of Baby M. (New York: Times Books). CoHen, C. (ed.) (1996), New Ways of Making Babies: The Case of Egg Donation (Bloomington:
Indiana University Press). (1999), 'Selling Bits and Pieces of Humans to Make Babies: The Gift of the Magi
Revisited', Journal of Medicine and Philosophy, 24/3:288-306.

Cohen, J. (2002), 'Grade A: The Market for a Yale Woman's Eggs', Atlantic Monthly, 290/5:
74-6. Labour', Bioethics, 15/3: 205-17.

Fielding, D., Handley, S., Duqueno, L., Weaver, S., and Lui, S. (1998), 'Motivation, Attitudes and Experience of Donation: A Follow-Up of Women Donating Eggs in Assisted Conception Treatment', Journal of Community and Applied Social Psychology, 8: 273-87.
RYE, M. (1983), The Politics of Reality: Essays in Feminist Theory (Fold

Frye, M. (1983), The Politics of Reality: Essays in Feminist Theory (Freedom, Calif.: Crossing
Press).

Gurmankin, A. D. (2001), 'Risk Information Provided to Prospective Oocyte Donors in a Preliminary Phone Call', American Journal of Bioethics, 1/4:3-13.

Holland, S. (2001), 'Contested Commodities at Both Ends of Life: Buying and Selling
Gametes, Embryos, and Body Tissues', Kennedy Institute of Ethics Journal, 11/3: 263-84.

KITTAY, E. F. (1999), Love's Labor: Essays on Women, Equality, and Dependency (New
York: Routledge). MACKENZIE, C. (1992), 'Abortion and Embodiment', Australian Journal of Philosophy, 70/2:
136-55.

Agency, and the Social Self (New York: Oxford University Press).
MCLEOD, C. (2002), Self-Trust and Restives on Autonomy,

MCLeOD, C. (2002), Self-Trust and Reproductive Autonomy (Cambridge, Mass.: MIT Press).

Kukla (ed.) Hyatia, suppl. vol. 21: Maternal Inalienability of Human Embryos', in R.

McSHater.

MCShane, P. M. (1996), 'Oocyte Donation Service at IVF America-Boston, Waltham,
Massachusetts', in Cohen (1996: 29-34).

Mahoney, J. D. (2000) 'The Mar: 29-34).

163-223.

MARX, K. (1844/1964), The Economic and Philosophic Manuscripts of 1844, ed. D. J. Struik, trans. M. Milligan (New York: International Publishers).

_. (1867/1954), Capital, ed. F. Engels, trans. S. Moore and E. Aveling (Moscow: Progress
Press). MeYers, D. T. (1989), Self, Society, and Personal Choice (New York: Columbia University
Press).

Morgan, K. P. (1991), 'Women and the Knife: Cosmetic Surgery and the Colonization of

Women's Bodies', Hypatia (Fall), 25-53. 
'phy and

:(2000), ty, 74/2:

nity and $33-44$.

ington:

e Magi

290/5:

luctive

ration,

isisted

3-87.

sssing

$s$ in $a$

elling

-84 .

New

70/2:

$m y$,

ess).

$1 R$.

am,

$5 / 2$ :

lik,

ess

ity

of

New York State Task Force on Life and the Law (1998), 'Assisted Reproductive Technologies: Analysis and Recommendations for Public Policy', Executive Summary, $<$ http://www.health.state.ny.us/nysdoh/taskfce/execsum.htm >.

(2002), Thinking of Becoming an Egg Donor? A Guidebook, <http://www.health.state.ny. us/nysdoh/infertility/pdf/1127.pdf $>$.

Nussbaum, M. (1995), 'Objectification', Philosophy and Public Affairs, 24/4: 249-91.

O'DonNelL, K. (2000), 'Legal Conceptions: Regulating Gametes and Gamete Donation', Health Care Analysis, 8: 137--54.

Pateman, C. (1988), The Sexual Contract (Stanford, Calif.: Stanford University Press). Radin, M. (1991), 'Reflections on Objectification', Southern California Law Review, 65:
341-54.

(1996), Contested Commodities: The Trouble with Trade in Sex, Children, Body Parts, and Other Things (Cambridge, Mass.: Harvard University Press).

(2001), 'Response: Persistent Perplexities', Kennedy Institute of Ethics Journal, 11/3: 305-15. RAGONE, H. (1994), Surrogate Motherhood: Conception in the Heart (Boulder, Col.: Westview
Press).

(1999), 'The Gift of Life: Surrogate Motherhood, Gamete Donation, and Constructions of Altruism', in L. L. Layne (ed.), Transformative Motherhood: On Giving and Getting in a Consumer Culture (New York: New York University Press), 65-88.

(2000), 'Of Likeness and Difference: How Race Is Being Transfigured by Gestational Surrogacy', in H. Ragone and F. Winddance Twine (eds.), Ideologies and Technologies of Motherhood: Race, Class, Sexuality, Nationalism (New York: Routledge), 56-75.

RoBerts, D. (1997), Killing the Black Body: Race, Reproduction, and the Meaning of Liberty (New York: Pantheon Books).

SATZ, D. (1992), 'Markets in Women's Reproductive Labor', Philosophy and Public Affairs, 21/2: 107-31.

Serafini, P. D., Nelson, J. R., Smith, S. B., Richardson, A., and Batzorin, J. (1996), 'Oocyte Donation Program at Huntington Reproductive Center: Quality Control Issues, Pasadena, California', in Cohen (1996: 35-48).

Shalev, C. (1989), Birth Power: The Case for Surrogacy (New Haven: Yale University Press).

SHERwiN, S. (1998), 'A Relational Approach to Autonomy in Health Care', in Feminist Health Care Ethics Research Network, The Politics of Women's Health: Exploring Agency and Autonomy (Philadelphia: Temple University Press), 19-47.

ShulTZ, M. M. (1990), 'Reproductive Technology and Intent-Based Parenthood: An Opportunity for Gender Neutrality', Wisconsin Law Review, 297: 287-398.

STEINBock, B. (2004), 'Payment to Egg Donors', Mount Sinai Journal of Medicine, 71/4: 255-65.

VANCE, C. S. (ed.) (1984), Pleasure and Danger: Exploring Female Sexuality (Boston: Routledge \& Kegan Paul). WALZER, M. (1983), Spheres of Justice: A Defense of Pluralism and Equality (New York: Basic
Books). 